\title{
PTH wt Allele
}

National Cancer Institute

\section{Source}

National Cancer Institute. PTH wt Allele. NCI Thesaurus. Code C52426.

Human PTH wild-type allele is located within 11p15.3-p15.1 and is approximately $4 \mathrm{~kb}$ in length. This allele, which encodes parathyroid hormone protein, plays a role in calcium homeostasis. Mutation or aberrant expression of this gene can result in hypoparathyroidism. 